\title{
A Bounds Test Approach to the Evaluation of Non-Oil Exports and Economic Growth in Nigeria
}

\author{
${ }^{1}$ Uzoma Chidoka Nnamaka Ph.D, ${ }^{2}$ Chukwuma - Ogbonna Joyce Adaku Ph.D, ${ }^{3}$ Odungweru Kingsley Ph.D \\ ${ }^{I}$ Rivers State Universal Basic Education Board, Port Harcourt, Nigeria \\ ${ }^{2}$ Department of Economics, College of Management Sciences, Michael Okpara University of Agriculture, Umudike, \\ Abia State, Nigeria. \\ ${ }^{3}$ Department of Economics, Faculty of Social Science, Rivers State University, Port Harcourt, Nigeria
}

\begin{abstract}
This study examined the relationship between non-oil exports and economic growth in Nigeria for the period 1981 to 2019 using ARDL/Bounds testing approach to analyse data sourced from the CBN statistical bulletin. The ADF stationary test showed that all the variables attained stationarity after first difference except gross domestic product which was stationary at levels. The bounds test confirmed the existence of a long run association amongst the variables in the model. Non-oil export and economic growth were positively related in both the long run and short run. While the long run revealed an insignificant relationship, a significant relationship was observed in the short run. Trade openness showed evidence of positive and insignificant relationship with economic growth both in the long run and in the short run period while exchange rate revealed a positive and significant relationship with economic growth both in the long run and in the short run period. The $R^{2}$ value indicates that 58 percent of the systematic variation in economic growth is explained by non-oil export, trade openness and exchange rate in Nigeria over the period under study. Based on these results, the study recommends: the diversification of the productive base of the nation to boost domestic capital formation needed for investment, prudent utilization of borrowed funds to reduce poverty to the barest minimum and more efficient debt management strategies to ensure that borrowed funds are directed to more productive channels in the economy to stimulate growth and improve the living standard of people.
\end{abstract}

Keywords: Non-oil export, Economic growth, AfCFTA, Nigeria, ARDL

\section{INTRODUCTION}

Exports are important growth stimulant as it affords economies the opportunity to access international markets to generate income. This implies that there exists a correlation between the growth of a country's exports and its overall growth (Kravis, 2000). The growth of export in an economy has forward and backward linkages to other sectors of the economy. Nigeria, as a developing country that is grappling with the realities of the developmental process is in dire need of foreign capital in order to accelerate the rate of economic growth (Adesoji and Sotubo, 2013). Prior to the oil boom of the 1970s, a reasonable proportion of Nigeria's export was from the non-oil sector ranging from agricultural to tin ore, columbite and a myriad of other non-oil commodities. Agriculture was the mainstay of the economy and the greatest foreign exchange earner. Its products constituted the bulk of Nigeria's non-oil exports. Non-oil export refers to the sale of commodities asides crude oil in the international market to generate revenue. Akeem (2011) noted that Nigeria's non-oil export comprises mainly of agricultural exports, manufactured exports, solid mineral exports and services exports. The shares of these products both processed and unprocessed in total value of non-oil exports was as high as 70 per cent (CBN, 2011). 1960 and 1970 saw the nonoil commodities market experiencing export boom. Their fortunes declined in the early 1980s when the international primary commodity market collapsed with the associated deterioration in the terms of trade. This was, however 
DOI: $\underline{10.51386 / 25815946 / i j s m s-v 4 i 4 p 128}$

Volume: 4 Issue: 4

July to August 2021

https://www.ijsmsjournal.org

ephemeral as the international demand for Nigeria's non-oil exports remained weak (Okoh, 2004). The contributions of the non-oil sub sector to economic growth has been below full capacity over the years. Due to limiting factors like small farm size, crude and outdated farm implements, inadequate access to credit facilities among others, agricultural sector which is the bane of non-oil exports in Nigeria has become characterized by low productivity (Aboganet al, 2014). The Agricultural sector was displaced by the oil sector in the mid-1970s from its prime position and since then, the Nigerian economy has been highly dependent on proceeds from oil, which constituted over 90 percent of total foreign exchange earnings required from financing several national development projects and the value of non-oil exports has been on the declining side. Invariably, the variations in crude oil prices in terms of changes in revenue automatically takes its toll on the economy of Nigeria. On the average, the exports earning in Nigeria is expanding but the composition of the exports calls for concern. Over the years, a major concern has been how to expand non-oil export in a bid to diversify the nations export base to increase its contribution to GDP. This concern is not just about its dismal performance in terms of market share loss in the non-oil trade globally but that it is not keeping up with oil export in Nigeria.

Oil exports accounted for about 95 percent of Nigeria's export earnings while the non-oil exports accounted for less than 5 percent on the average between 1980 and 2004 (CBN, 2005). In 2010, non -oil exports constituted about 33 percent of the total exports in Nigeria while oil exports made up the rest (CBN, 2011).

Non-oil exports rose from $\$ 500.9$ billion in 2009 to $\$ 913.5$ billion in 2011. The figure dropped to $\$ 656.8$ billion in 2016 before rising to 1.43 trillion in 2018. Non-oil export figures stood at N3.2 trillion in 2019 but as a result of a consistent decline in the second, third and quarters of 2020, the value of non-oil export dropped to N3.08 trillion by the end of the year.

A viable solution for sustainable economic growth in Nigeria as a developing oil producing country is the expansion of the non-oil exports. Over the years, several policies have been put in place to improve non-oil exports. Amongst the recent policies is the establishment of the Non-oil export facility in 2018 aimed at improving exporter's access to concessionary finance and encourage reinvestment in value-added, non-oil export production. A more recent policy is the appointment of pre-shipment inspection agents (PIA's) to ascertain the quality, quantity and price competitiveness of exports from Nigeria. Furthermore, the federal government in 2020 approved the ratification of Nigeria's membership of the African Continental Free Trade Area (AfCFTA) followed by the signing of the AfCFTA agreement on March 2021. This move will afford the nation the opportunity to access the regional and continental market depending on the nation's competitiveness. Also, the area's single market will eliminate tariffs on 90 percent of goods produced in the continent. Another benefit of AfCFTA membership is the free movement of labour, goods, services and capital within the area. The past policies and strategies have not yielded commendable results in improving non-oil exports in Nigeria. In the light of this background, this study is aimed at examining the effect of non-oil export on economic growth in Nigeria. The rest of this study is structured into literature review, methodology, results and discussions and finally, conclusion and recommendations.

\section{Literature Review}

The theoretical foundation of the study is the export-led growth hypothesis (ELGH). It posits that an expansion in exports promotes specialization in production of export products which in turn boosts productivity levels thereby causing the general level of skills to rise in the export sector. This in turn leads to a reallocation of resources from the inefficient non-trade sectors of the economy to the higher productive export sector. This productivity change leads to output growth. In a nutshell, the ELGH emphasizes export as the key determinant of economic growth.

A well-managed openness to trade through an export led growth can be an avenue to achieve rapid economic growth although practical evidence in support of export led growth may not be universal (Giles and Williams, 2000). The proponents of open trading argued that an open market policy leads to a proportional increase in Gross Domestic Product alongside other positive externalities (Mankiwet al, 1992). 
According to Todaro\& Smith (2011), Export promotion strategies are aimed at encouraging exports, often through export incentives in the form of public subsidies, tax rebates, special credit lines and other kinds of financial and non-financial measures designed to improve economic activities in export industries in order to generate more foreign exchange and improve the current account of the balance of payments. Abou-Strait (2005), rightly noted that export led growth strategies are aimed at providing producers with incentives to export their goods through various economic and governmental policies aimed at increasing the level of national output and increasing the volume of exports of the nation. Various studies exist on non-oil export and economic growth. For instance, Akeem (2011) carried out a study on the determinants of non-oil export and economic growth in Nigeria using time series data from 1989 to 2008 using multi linear regression method. Findings from their study showed that non-oil export for previous year and consumer price index impacted positively on GDP in Nigeria.

Ezike and Ogege (2012) investigated the impact of foreign trade policy on non-oil export in Nigeria using both correlation analysis and least square techniques. Their result showed that there exists a positive relationship between economic growth and non-oil export in Nigeria. The study therefore recommended that the diversification of the export base of the nation through trade policies that focuses on production and exportation of nonoil products.

Onodugo, Marius, and Oluchukwu (2013) set out in their study to examine non-oil export and economic growth in Nigeria for the period 1981 to 2012 using the Johansen co integration technique. Their result showed that non-oil exports did not impact significantly on economic growth in Nigeria.

Adeniyi and Saidi (2014)analysedthe impact of aggregate non-oil sector and its determinant on economic growth in Nigeria using the bound test approach. The result shows that non-oil export impacted positively on economic growth both in the long and short run periods.

Ifeacho, Omoniyi, \&Olufemi (2014) set out in their study to investigate the effect of non-oil export on the economic development of Nigeria using the ordinary least square estimating technique. their result showed that non-oil export exhibited a significant positive relationship with per capita income. Furthermore, their result showed that the coefficient of trade openness was negative implying that Nigeria might not have been benefiting enough from trade with other countries. This shows that trading partners of Nigeria are gaining more from trade transactions than Nigeria. They recommended a review of trade policy in Nigeria.

Ogunjimi, Aderinto\&Ogunro (2015) set out in their study to analyze the relationship between non-oil sector and economic growth from 1980 to 2012. Findings from their study showed that non-oil export exerted a negative and insignificant effect on economic growth in Nigeria exposing the dismal performance of the sector. The study in conclusion stressed on the need for the government to focus on reviving the sector to improve its performance and repositioning to meet international standards.

Adewale, Ayo \&Abayomi (2016) investigated the impact of non-oil export on the Nigerian economy from 1970 to 2014 using the OLS technique. Their result showed that non-oil export had a significant negative impact on GDP while openness and exchange rate exerted positive influences on GDP over the period under review. They stressed on the need to diversify the Nigerian economy from its dependency on oil through the promotion of non-oil exports as a major source of foreign exchange earnings.

Kawai (2017) examined the impact of non-oil exports on the growth of Nigerian economy between 1980 and 2016 using the Engel- Granger Model (EGM) for co-integration. Findings from their study showed a strong evidence of co-integration relationship between non-oil exports and economic growth in Nigeria. The study therefore recommends that government re-emphasize and strengthen sector by sector revolution plan. 


\section{DOI: $\underline{10.51386 / 25815946 / i j s m s-v 4 i 4 p 128}$}

Volume: 4 Issue: 4

July to August 2021

https://www.ijsmsjournal.org

Adopting the autoregressive distributed lag (ARDL) model approach, Kromtit, et al,(2017) analysed the contribution of non-oil exports to economic growth in Nigeria for the period, 1985 to 2015. Their findings revealed a positive and significant relationship between non-oil exports and economic growth in Nigeria. Their result also showed that exchange rate had an insignificant negative on GDP in Nigeria. The study therefore recommended that credit be provided to the non-oil sectors at lower interest rate.

In investigating the impact of non-oil exports on economic growth in Nigeria from 1980 to 2016, Olawale (2018) adopted the Fully Modified Ordinary Least Square (FMOLS) and Bounds test for cointegration methods. His result revealed the existence of long-run equilibrium relationship between the variables. It further showed a positive and significant impact of non-oil export on economic growth in Nigeria for the period covered by the study. The study however recommended that government provides infrastructural framework to broaden the non-oil export base.

Uzonwanne (2020) examined the role of selected non-oil commodities exports on economic growth in Nigeria using quarterly time series data from 2010 to 2017. The ARDL result showed that hides and skins; rubber and plastic export, and textile and textile articles exerted positive but insignificant effects on real GDP which was used as a proxy for economic growth. The result further showed that there exists a bi-directional causality between the real GDP and the non-oil export items. The study therefore recommended that government should diversify the economy by taking a deeper look in to de-emphasizing mono-economy system.

\section{METHODOLOGY}

The study adopted the ex-post facto research design to test hypotheses about cause-and-effect relationships. The study used secondary data sourced from Central Bank of Nigeria (CBN) statistical bulletin from 1981 to 2019. The functional form of the model is therefore presented as follows:

GDP $=\mathrm{f}(\mathrm{NOX}, \mathrm{TOP}, \mathrm{EXR})$.

To eliminate the differences in the unit of measurement, a logarithm form of specification is important. The log linear form of both sides of equation 1 is stated as follows:

$\mathrm{LnGDP}_{\mathrm{t}}=\beta_{0}+\beta_{1} \operatorname{lnNOX} \mathrm{t}+\beta_{2} \operatorname{lnTOP}{ }_{\mathrm{t}}+\beta_{3} \mathrm{EXR}_{\mathrm{t}}+\mu_{t}$

Where: GDP = Gross Domestic Product (proxy for economic growth)

$$
\begin{aligned}
& \text { NOX }=\text { Non-oil Export } \\
& \text { TOP }=\text { Trade Openness } \\
& \text { EXR }=\text { Exchange Rate } \\
& \beta_{0} \quad=\text { intercept } \\
& \beta_{1}-\beta_{3}=\text { parameter estimates } \\
& \mu_{t} \quad=\text { error term }
\end{aligned}
$$

On the apriori, it is expected that;

The ADF unit root test helps to ascertain the stationarity status of the variables. It makes an improvement on the Dickey \& Fuller (1979) stationarity test because it addresses the problem autoregressive process and applies the same procedure as the Dickey-Fuller test. The model for the unit root test is specified including a drift and deterministic trend as follows: 
$\Delta Y_{\mathrm{t}}=\alpha_{0}+\alpha_{1} Y_{\mathrm{t}-1}+\sum_{i=1}^{k} \beta \mathrm{i} \Delta Y_{\mathrm{t}-\mathrm{i}}+\mu_{\mathrm{t}}$

Where $Y_{t}=$ vector of the variables under investigation, $Y_{t-1}=$ one period lag of the underlying economic under investigation, $\alpha_{0}=$ drift or intercept, $\alpha_{1} \& \beta_{\mathrm{i}}=$ parameters to be estimated, $k=$ maximum lag length, $\Delta=$ first difference notation, $\mathrm{u}_{\mathrm{t}}=$ white noise.

In order to examine both the long run and short run relations between economic growth and non-oil export variables in the model, Autoregressive Distributed Lag (ARDL)/bound test approach to co-integration, proposed by Pesaran et al (2001) was adopted. The null hypothesis of no cointegration is tested against the alternative hypothesis of cointegration. The ARDL cointegration technique is preferable to other cointegration techniques because it is applicable to variables that are integrated of different order, $\mathrm{I}(0), \mathrm{I}(1)$ or a combination of the both. The approach also identifies cointegrating vectors where there are multiple cointegrating vectors. The technique however will crash in the presence of integrated stochastic trend of I(2) series. Restating equation (1) as an ARDL model we have:

$\Delta \mathrm{GDP}_{\mathrm{t}}=\delta_{0}+\delta_{1} \mathrm{GDP}_{\mathrm{t}-1}+\delta_{2} \mathrm{NOX}_{\mathrm{t}-1}+\delta_{3} \mathrm{TOP}_{\mathrm{t}-1}+\delta_{4} \mathrm{EXR}_{\mathrm{t}-1}+\sum_{\mathrm{i}=1}^{\mathrm{n}} \theta_{1 \mathrm{i}} \Delta \mathrm{GDP}_{\mathrm{t}-1}+\sum_{\mathrm{i}=0}^{\mathrm{n}} \theta_{2 \mathrm{i}} \Delta \mathrm{NOX}_{\mathrm{t}-1, \mathrm{j}}+\sum_{\mathrm{i}=0}^{\mathrm{n}} \theta_{3 \mathrm{i}} \Delta \mathrm{TOP}_{\mathrm{t}-1}$ $+\sum_{\mathrm{i}=0}^{\mathrm{n}} \theta_{4 \mathrm{i}} \Delta \mathrm{EXR}_{\mathrm{t}-1}+\lambda \mathrm{ECM}_{\mathrm{t}-1}+\mu_{\mathrm{t}}$

Where $\Delta$ denotes the difference operator

nis the optimal lag length

$\delta_{0}$ is the vector of the intercept

$\delta_{1}-\delta_{4}$ is the long run elasticities

$\theta_{1}-\theta_{4}$ is the short run dynamic coefficient

$\mu_{t}$ is the error term

$\mathrm{ECM}_{\mathrm{t}-1}$ is the error correction term

$\lambda$ is the error coefficient which shows the rate at which the model corrects the speed of adjustment of the previous period's disequilibrium to restore the long run equilibrium relationship. Traditionally, the coefficient of ECM is expected to be negative and statistically significant implying that any movement in short run between the dependent and independent variables will converge back to the long run equilibrium. The greater the co-efficient of the error correction term, the higher the speed of adjustment of the model from the short-run to the long-run.

The null hypothesis of no cointegration is tested under the asymptotic distribution of the F-statistic. From the ARDL model in equation (2), the null and the alternative hypotheses are expressed respectively below:

$\mathrm{H}_{0}: \delta_{1}=\delta_{2}=\delta_{3}=\delta_{4}=0$

$\mathrm{H}_{1}: \delta_{1}=\delta_{2}=\delta_{3}=\delta_{4} \neq 0$

Pesaranet al (2001) reported two sets of critical values. One critical value requires that all the variables in the ARDL model are I(0), while, the other assumes that the variables are I(1). If the computed F-statistic is greater than the upper bound I(1) of the critical value, the null hypothesis of no cointegration would be rejected. However, if the falls below the lower bound, the null hypothesis of no cointegration cannot be rejected. The test is however inconclusive if the F-statistic falls in between the bounds. 
DOI: $\underline{10.51386 / 25815946 / i j s m s-v 4 i 4 p 128}$

Volume: 4 Issue: 4

July to August 2021

https://www.ijsmsjournal.org

RESULTS AND DISCUSSION

TABLE 1: UNIT ROOT TEST

\begin{tabular}{|l|l|l|l|l|l|}
\hline VARIABLE & ADF Test & $\begin{array}{l}\mathbf{1 \%} \text { Critical } \\
\text { Value }\end{array}$ & $\begin{array}{l}\mathbf{5 \%} \text { Critical } \\
\text { Value }\end{array}$ & $\begin{array}{l}\mathbf{1 0 \%} \text { Critical } \\
\text { Value }\end{array}$ & $\begin{array}{l}\text { Order } \\
\text { Integration }\end{array}$ \\
\hline GDP & -3.047477 & -3.615588 & -2.941145 & -2.609066 & $\mathrm{I}(0)$ \\
\hline NOXP & -7.070127 & -3.621023 & -2.943427 & -2.610263 & $\mathrm{I}(1)$ \\
\hline TOP & -3.208447 & -3.621023 & -2.943427 & -2.610263 & $\mathrm{I}(1)$ \\
\hline EXR & -5.131443 & -3.621023 & -2.943427 & -2.610263 & $\mathrm{I}(1)$ \\
\hline
\end{tabular}

From Table 1, the ADF test result showed that at 5 percent level of significance, non-oil export, trade openness and exchange rate were integrated of order one as their respective ADF statistics were greater than 5 per cent critical values, while real gdp was stationary at levels. Having established that the variables were integrated of order $1(0)$ and 1(1), the requirement to fit in an ARDL model to test for long run relationship is met.

Table 2: ARDL Bounds Test for Co-integration Model

\begin{tabular}{|l|c|l|c|c|}
\hline Test Statistic & Value & Significance & I0 Bound & I1Bound \\
\hline F-statistics & 3.903997 & $10 \%$ & 2.63 & 3.35 \\
\hline K & 3 & $5 \%$ & 3.1 & 3.87 \\
\hline \multirow{2}{*}{} & $2.5 \%$ & 3.55 & 4.38 \\
\cline { 2 - 5 } & $1 \%$ & 4.13 & 5 \\
\hline
\end{tabular}

Source: Computed Result Using (E-Views 10)

The bounds test result in table2 showed that the calculated F-statistic value of 3.903997 exceeded the upper bound critical value of 3.87at five percent level of significance. Thus, the null hypothesis of no cointegration is rejected, confirming the existence of a long-run cointegrating relationship between the variables. Following the establishment of a long run run cointegration relationship, the study obtained the long-run and short-run dynamic parameters for the variables.

Table 3: ARDL Long Run Result for the Estimated Model Dependent Variable: LPOV

\begin{tabular}{|c|r|r|r|c|}
\hline Variable & Coefficient & Std. Error & t-Statistic & Prob. \\
\hline LNOXP & 0.031515 & 0.039713 & 0.793584 & 0.4326 \\
\hline LTOP & 0.170525 & 0.169497 & 1.006061 & 0.3222 \\
\hline EXCR & 0.016701 & 0.006592 & 2.533331 & 0.0164 \\
\hline C & 0.534887 & 0.259460 & 2.061542 & 0.0480 \\
\hline
\end{tabular}

Source: Computed Result Using (E-Views 10)

From table 3, the estimated ARDL long run coefficient of non-oil export was positively signed and insignificant with economic growth. This implies that non-oil export impacted positively on economic growth in Nigeria for the period covered by the study although the impact was not insignificant in the long-run. This corroborates the works of Ogunjimi, Aderinto\&Ogunro (2015), Omojolaibi, Mesagan\&Adeyemi (2015) and Uzonwanne (2020)who also observed a positive and insignificant relationship between non-oil export and economic growth in Nigeria. The study by Aladajare\&Saidi (2014) however showed a significant impact of non-oil export on economic growth in the long run. Trade openness and exchange rate also showed positive relationships with economic growth. While the relationship of trade openness exerted an insignificant effect on economic growth, that of exchange rate was significant. 
DOI: $\underline{10.51386 / 25815946 / i j s m s-v 4 i 4 p 128}$

Volume: 4 Issue: 4

July to August 2021

https://www.ijsmsjournal.org

Table 4:ARDL Error Correction Model Result for the Estimated Model

\begin{tabular}{|c|c|r|r|r|}
\hline Dependent Variable: POV \\
\hline Variable & Coeff. & Std. Error & t-Statistic & Prob. \\
\hline D(LGDP(-1)) & 0.429449 & 0.165687 & 2.591937 & 0.0141 \\
\hline D(LNOXP) & 0.095499 & 0.026858 & 3.555626 & 0.0013 \\
\hline D(LNOXP(-1) & 0.062409 & 0.031418 & 1.986454 & 0.0562 \\
\hline D(LTOP) & 0.149928 & 0.097175 & 1.542865 & 0.1327 \\
\hline D(EXCR) & 0.015093 & 0.005797 & 2.603408 & 0.0139 \\
\hline CointEq(-1)* & -0.080163 & 0.026409 & -3.035389 & 0.0049 \\
\hline $\mathrm{R}^{2}=0.58$, & F-stat $=49.98$, & D.W $=1.89$ \\
\hline
\end{tabular}

Table 4 shows the result of the short-run dynamic coefficients obtained from the ECM equation. The current and the one lagged values of non-oil export were positive and significant at 5 percent level in line with theoretical expectations. This is similar to the submissions of Isholaet al (2013), Ifeachoet al (2014), Adewaleet al (2016), Kawai (2017) and Olawale (2018) that a positive and significant effect exists between non-oil export and economic growth in Nigeria.

Similar to the long run result, the coefficient of trade openness in the short-run had the right sign (positive) as expected a priori, but was not statistically significant at 5 percent level in line with the position of Adewaleet al, (2016). The insignificant relationship trade openness has with economic growth implies that the Nigerian economy has not been benefiting fully from trade with other economies of the world. Exchange rate in the short- run had positive and significant relationship with economic growth just like in the long run. This finding is consistent with the empirical studies of Ifeachoet al, (2014), Adewaleet al, (2016), Aladejare\&Saidi (2014) \&Omojolaibi, Mesagan\&Adeyemi (2016) who reported that exchange rate has a positive and significant impact on economic growth in Nigeria.

Furthermore, the error correction term in the model was rightly signed (i.e., negative) and statistically significant at conventional levels implying that deviations from the long-term economic growth adjusts to long run equilibrium at a speed of 8 percent. This slow speed of adjustment is reflective of the fact that the Nigerian economy has not been fully diversified. The $\mathrm{R}^{2}$ value indicates that 58 percent of the systematic variation in economic growth is explained by non-oil export, trade openness and exchange rate in Nigeria over the period under study. The Durbin Watson statistic of 1.89 suggests the absence of serial correlation.

\section{Figure 1: CUSUM Test of Stability}

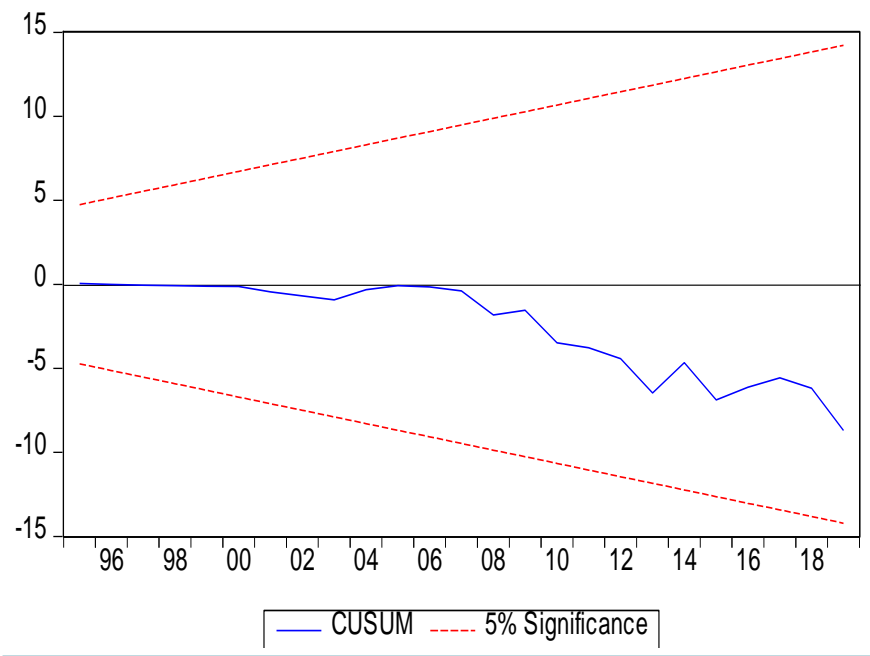


The stability of the parameters of the model was examined using the plot of the cumulative sum of recursive residuals (CUSUM). The CUSUM line did not extend beyond the 5 percent critical line, affirming the stability of the long-run and short-run coefficients of the independent variables on economic growth in Nigeria throughout the period covered by the study.

\section{CONCLUSION}

This study used the bounds testing approach to examine non-oil export and economic growth in Nigeria from 1981 to2019 with time series data sourced from CBN Statistical Bulletin. The variables were subjected to unit root test using the ADF. The test result showed that all the variables except real gross domestic product attained stationary after first difference. The bounds test confirmed the existence of a long run association amongst the variables in the model. Non-oil export and economic growth were positively related in both the long run and short run. While the long run revealed an insignificant relationship, a significant relationship was observed in the short run. Trade openness showed evidence of positive and insignificant relationship with economic growth both in the long run and in the short run period while exchange rate revealed a positive and significant relationship with economic growth both in the long run and in the short run period. The study therefore recommends that government should formulate viable long term economic policies in favour of non-oil sector's production to diversify the productive base of the nation. Also the government, through the pre-shipment inspection agents (PIA's) should ensure that the non-oil export products have the right quality and are price competitive so that the nation can maximize the benefits from openness to trade. Finally, the central bank of Nigeria $(\mathrm{CBN})$ should give concession to the non-oil sector in terms of foreign exchange allocation to boost their production for exports.

\section{REFERENCE}

[1] Abogan, O. P., Akinola, E. B.,\&Baruwa, O. I. (2014). Non-oil export and economic growthin Nigeria (1980-2011).Journal of Research in Economics and International Finance, 3(1), 1-11. http:/dx.doi.org/10.14303/jrief.2013.045

[2] About-Stait, F. (2005). Are exports the engine of economic growth? An application ofcointegration and causality analysis for Egypt, $1977-$ 2003. Economic ResearchWorking Paper, 76, Tunis: African Development Bank.

[3] Adeniyi, A. S. \&Saidi, A. (2014). Determinants of Non-oil Export and Economic Growth in Nigeria: An Application of the Bound Test Approach. Journal for the Advancement of Developing Economies.3(1), 60-71.

[4] Adenugba, A. A., \&Dipo, O. S. (2013). Non-Oil exports in the economic growth of Nigeria:A study of agricultural and mineral Resources. Journal of Educational and SocialResearch, 3 (2), 403-418.

[5] Adesoji, A. A. Sotubo, O. D. (2013). Non-Oil exports in the economic growth of Nigeria: a study of agricultural and mineral resources. Journal of Educational and Social Research. 3(2), 403-418.

[6] Adewale, E.A., Ayo, A. A., \&Abayomi, A. (2016).The Impact of Non-oil Export on the Nigerian Economy.https://www.researchgate.net/publication/340515268

[7] Akeem, O. U. (2011). Non oil export determinant and economic growth. European Journal ofBusiness Management, 3 (3),236-257.

[8] Central Bank of Nigeria (CBN) (2005).Statement of Accounts and Annual Reports.Abuja:Central Bank of Nigeria.

[9] Central Bank of Nigeria (CBN) (2010).Statement of Accounts and Annual Reports.Abuja:Central Bank of Nigeria.

[10] Ezike, J.E. and Ogege, S. (2012). Nigerian foreign trade policy: Its impact on non-oil exports.Journal of Economics and International Finance. 4(8), 192-200.

[11] Giles J. A. \& Williams C. L. (2000). Export-led growth: a survey of the empirical literature and some noncausality results, part 2.

[12] Ifeacho, C., Omoniyi, B.O, \&Olufemi O. B. (2014).Effects of Non-Oil Export on the Economic Development of Nigeria.International Journal of Business and Management Invention. 3(3), 27-32

[13] Ishola, S. A., Ajayi, E. O., Onafowokan I. \&Giwa A. B. (2013). Trade openess and Economic Growth in Nigeria (1981 - 2009) An Empirical Analysis.International Journal of Humanities and Social Science Invention.2(6),101-113. 


\section{DOI: $10.51386 / 25815946 /$ ijsms-v4i4p128}

Volume: 4 Issue: 4

July to August 2021

https://www.ijsmsjournal.org

[14] Kawai, V. (2017).An Analysis of the Impact of Non-Oil Exports and Economic Growth in Nigeria from 1980 - 2016. International Journal of Innovative Research in Social Sciences \& Strategic Management Techniques. 4 (2), 83-94.

[15] Mankiw, N. G., Romer, D. \& Weil, D. N. (1992).A contribution to the empirics of economic growth.Quarterly Journal of Economics. $10(7), 407-437$.

[16] Matthew, J., Kromtit, C.,Kanadi, D. P. \& Suleiman, L. (2017). Contribution of non-oilexports to economic growth in Nigeria (1985-2015), International Journal ofEconomics and Finance, 9 (4), https://doi.org/10.5539/ijef.v9n4p253

[17] Ogunjimi, O., Aderinto, E. \&Ogunro T. (2015).An Empirical Analysis on the Relationship between Non-Oil Exports and Economic Growth in Nigeria.International Journal of Academic Research in Business and Social Sciences. 5 (12), 68-78.

[18] Okoh, R. N. (2005). Nigeria's Non-Oil Export Product Mix and the Competitive GlobalMarket Place. The Union Digest. 9(3\&4):63-82.

[19] Olawale, H. (2018). Promoting Nigerian Non-Oil Export in the Global Market and its Impacts on Economic Growth in Nigeria.International Journal of Advanced Studies in Economics and Public Sector Management. 6(2), 86-100.

[20] Onodugo, V., Marius, I., \&Oluchukwu, A. F. (2013).Non-oil export and economic growthin Nigeria: A time series econometric model. International Journal ofBusinessManagement and Research, 3 2),115

[21] Pesaran, M.H., Shin, Y., \& Smith, R. (2001).Bounds testing approaches to the analysis of level relationships.Journal of Applied Econometrics, 16(1), 289-326.

[22] Todaro, M. P., \& Smith, S. C. (2011).Economic development (11th ed.). USA: Addison Wesley.

[23] Uzonwanne, M. C. (2020). Non-oil export and economic growth in Nigeria: A disaggregated analysis. Turkish Economic Review. 7(1), 115.

[24] Waithe, K., Lorde, T., \& Francis, B. (2011). Export-led growth: A case of Mexico. International Journal of Business, Humanities and Technology, 1(1) 21-30. 